\title{
Audit Committee Attributes, Corporate Governance and Voluntary Disclosure: Evidence from Jordan
}

\author{
Mohammad Abdullah Fayad Altawalbeh \\ Accounting department, business faculty, Tafila Technical University, Jordan, E-Mail: Tawalbeh@ttu.edu.jo
}

\begin{abstract}
This study examines the impact of audit committee attributes, corporate governance on voluntary disclosure of the non-financial firms listed on Amman stock exchange, the sample size consists of 72 listed firms covered the time period 2013-2016. Voluntary disclosure was measured using the relative disclosure index ratio. Multiple regression techniques were employed to test the study hypotheses, the results show that audit committee independence and audit committee meetings frequency have a significant positive impact on the level of voluntary disclosure, the results also revealed that independent board members and foreign ownership have a significant positive impact on the level of voluntary disclosure, however, family control exerts a negative significant impact on the level of voluntary disclosure. The findings of this study may have policy implications for the Jordanian corporate governance regulators as well as to regulators in the developing countries.

Key words

Audit Committee, Voluntary Disclosure, Corporate Governance, Family Control

\author{
Received: 20 Jun $2020 \quad$ C The Authors 2020 \\ Revised: $\quad 23$ Jul $2020 \quad$ Published by Human Resource Management Academic Research Society (www.hrmars.com)
}

Accepted: $\quad 02$ Aug 2020 This article is published under the Creative Commons Attribution (CC BY 4.0) license. Anyone may Published Online: 06 Aug $2020 \quad$ reproduce, distribute, translate and create derivative works of this article (for both commercial and non-commercial purposes), subject to full attribution to the original publication and authors. The full terms of this license may be seen at: http://creativecommons.org/licences/by/4.0/legalcode
\end{abstract}

\section{Introduction}

Voluntary disclosure is considered as an external factor which is expected to help in protecting stakeholders, reducing information asymmetry and decreasing agency cost results from information asymmetry between managers and stakeholders, as such, several studies have been conducted to address the critical role of voluntary disclosure in developed and developing countries (Herath \& Altamimi, 2017). The main goal of corporate governance system is to safeguard the provision of an environment characterized by trust, transparency and accountability necessary to enhance investment and financial stability (Altawalbeh, 2020).

Audit committee is a permanent committee formed by the board of directors for the purpose of overseeing and monitoring accounting and internal control and auditing activities in the company. As a rule this committee should have a majority of independent board members (Habbash, 2010). The Jordanian code of corporate governance (2017) provides a description of the qualifications and functions of the Audit committee including the responsibility to ensure the company adherence to applicable regulations and disclosure policy. Thus, Audit committee is viewed as a monitoring tool to bridging the gap of information asymmetry which in turn results in minimizing agency costs. (Allegrini \& Greco, 2013) argued that Audit committee works as a control tool over the management's decisions and behaviors, in addition, Audit committee improves the reporting policy by ensuring a sufficient level of voluntary disclosure to serve the investor's needs. (Martnez \& Fuentes, 2007) suggested that Audit committee will be more effective in 
supervising the preparation of financial statements in accordance with international standards and in reducing disputes between management and the external auditor to avoid receiving a modified audit report. The audit committee is considered an integral part of corporate governance that tends to improve the effectiveness of institutional control over The CEO, as well as a mechanism to improve management accountability towards the shareholders and other stakeholders (Moxey, 2004). In light of agency theory, Audit committee is delegated an important role in monitoring the management practices towards transparency including an appropriate level of voluntary disclosure, if this role is achieved as required by the international standards, it is expected to enhance the public trust in the financial statement content (Bedard \& Gendron, 2008). Researchers have sought to examine the role of audit committee in enhancing corporate voluntary disclosure, (Akhtaruddin \& Haron, 2010) have used a sample of 124 public listed companies in Malaysia to investigate the impact of an effective audit committee and board ownership on corporate voluntary disclosure, the results indicated that the negative association between board ownership and voluntary disclosure is weaker for firms with an independent audit committee, on other words, audit committee independence moderates the negative impact of board ownership on voluntary disclosure, the findings recommended that firms with a higher level of board ownership should ensure high level of independent audit committee members. Ho \& Wong (2001) have investigated the role of corporate governance mechanisms on the level of corporate voluntary disclosure using four major corporate governance attributes with the extent of voluntary disclosure provided by listed firms in Hong Kong. Corporate governance attributes are the proportion of independent directors to total number of directors on the board, the existence of audit committee, CEO/Chairman duality, and the percentage of family members on the board. Using a weighted disclosure index for measuring voluntary disclosure, the results indicate that the existence of an audit committee is significantly and positively related to the extent of voluntary disclosure. Dezoort et al. (2002) argued that determinants of Audit committee effectiveness include four main dimensions. First, sufficient human resources, second; member's experience, independence and integrity, third; motivations includes incentives and rewards, Fourth; power and relevant regulations that clearly set duties and responsibilities. More specific, previous studies have revealed mixed results about the impact of audit committee attributes on voluntary disclosures.

\section{Literature review and hypotheses development}

\subsection{Audit committee independence}

Audit committee independence is expressed by the proportion of non executive audit committee members, it is believed that independence enhances the power of audit committee in monitoring management behaviors and in enhancing financial reporting quality including the disclosure practices as well (Madi et al., 2014). Duchin et al. (2010) suggested that large number of independent audit committee members would improve the objectivity, reliability, and transparency of the firm's financial reporting and voluntary disclosures. Taylor et al. (2011) have reported a significant positive association between the existence of independent audit committee members and the level of corporate voluntary disclosure. In contrast, (Li et al., 2012); Ismail \& Rahman (2011) could not find significant evidence about the association between audit committee independence and corporate disclosure.

H1: audit committee independence has a significant positive impact on the level of voluntary disclosure

\subsection{Audit committee meetings frequency}

Frequency of audit committee meetings refers to the number of meetings held by audit committee members during the reporting period; Li et al. (2012) found that at least four audit committee meetings during the year is significantly and positively related to the level of voluntary disclosure, they argued that audit committee meetings in a regular basis enhance the committee ability to perform its monitoring function. Appuhami \& Tashako (2017) have examined the association between audit committee characteristics and voluntary corporate social responsibility, data was collected from 300 listed firms annual reports, the results found that audit committee size, frequency of meetings, committee independence and gender diversity have a significant positive impact on the level of corporate social responsibility disclosure. Kelton \& Yang (2008) have investigated the impact of different corporate 
governance attributes on financial reporting behaviors including internet disclosure, data was collected using a sample of 583 US listed firms, the results found a positive association between frequency of audit committee meetings and the level of internet financial disclosure.

As knowledge is power, accounting and financial background of audit committee members simplifies their function in examination the financial statements to assess compliance with international standards and best practices. Depending on the previous discussion, the second hypothesis will be as follows:

H2: audit committee meeting frequency has a significant positive impact on the level of voluntary disclosure

\subsection{Audit committee size}

Resource dependency theory suggests that larger audit committee are more able to offer better resources and authority to effectively carry out their responsibilities (Allegrini \& Greco, 2013), larger audit committee is expected to bring diversity of opinions, knowledge, experiences to ensure effective monitoring functions (Bedard \& Gendron, 2010). Madi et al. (2014) have examined the effect of audit committee characteristics on the level of corporate voluntary disclosure using data for 146 Malaysian public listed companies for the year 2009. Multiple regression analysis revealed that audit committee independence, audit committee size and multiple directorships of audit committee members are positively and significantly associated with the level of corporate voluntary disclosure, while Number of audit committee Meetings and member's financial experience are not significantly associated with corporate voluntary disclosure. The results offer evidence to policy makers on the extent to which audit committee characteristics associated with the committee effectiveness in monitoring corporate reporting practices. Allegrini \& Greco (2013) examined the association between corporate governance and voluntary disclosure, seven corporate governance attributes were regressed against the index of voluntary disclosure, the results found a positive impact of both the board and the audit committee meeting frequency on voluntary disclosure. They concluded that diligent monitoring activities are related to greater transparency to outside parties. Pearson (2009) examined the association between audit committee attributes and voluntary disclosure using a sample of firms that were investigated by Security Exchange Commission and found nofraud firms, the results revealed that firms with higher voluntary disclosure were likely to have larger independent audit committee that met more often. The researcher argued that audit committee size and meeting frequency indicate the firms' propensity to make any voluntary disclosure. Mangena \& Pike (2005) found no significant association between the size of audit committee and voluntary disclosure. Therefore, the following hypothesis states that:

H3: audit committee size has a significant positive impact on the level of voluntary disclosure

\subsection{Audit committee financial and accounting experience}

Previous studies have found a significant role of financial and accounting expertise in improving the level of voluntary disclosure (Akhtaruddin \& Haron, 2010), empirical study of Li et al. (2012) revealed that adequate accounting and financial expertise of audit committee members positively impact the level of voluntary disclosure, in the same context, Huangand \& Thiruvadi (2008) provide evidence of a strong relationship between audit committee accounting expertise and significant relationship between audit committee's financial expertise and fraud prevention. On the contrary, Appuhami \& Tashakor (2017) found no evidence about the relationship between accounting expertise of audit committees and the level of corporate social responsibility disclosure, also Madi et al. (2014), Othman et al. (2014) found no significant association between financial expertise of audit committee members and voluntary disclosure. Therefore, the third hypothesis states that:

H4: audit committee expertise has a significant positive impact on the level of voluntary disclosure

\subsection{Board size}

Board size is expected to play an important role in mitigating agency problems, over the world, corporate governance codes requires listed firms to have large and independent board of directors (Gregory, 2009). Numerous previous studies have investigated the impact of board size on the corporate voluntary disclosure with mixed results, larger board size is expected to provide variety of experience; 
financial and managerial experts as well (Laksmana, 2008), having diverse experiences and opinions would enhance the board's monitoring ability in providing more voluntary disclosure (Gandia, 2008). Larmou \& Vafeas (2010) argued that a larger board provides more knowledge, more experts and improves monitoring functions in protecting stakeholder's rights and mitigating information asymmetry. On the other hand, Ahmed et al. (2006) suggested that a board with large size is expected to have less monitoring ability and thus provide less corporate disclosure, in the same context; Lipton \& Lorsh (1992) argued that large board size is expected to be less effective in achieving monitoring functions as a result of difficult arrangement of activities and poor consensus which is expected to result in less corporate disclosure. Empirical studies have provided evidence that board size positively impact the level of corporate disclosure; Al-janadi et al. (2013) have examined the impact of corporate governance mechanisms on corporate voluntary disclosure, using a sample of 87 listed firms in Saudi stock market, the results revealed that corporate governance mechanisms play a vital role in enhancing disclosure quality, more specific, board independence, board size, CEO duality and government ownership have positively and significantly impact voluntary disclosure, (Allegrini \& Greco, 2013; Akhtaruddin et al., 2009; Cheng \& Courtenay, 2006, Barako et al., 2006) have provided the same result. Depending on the previous discussion this study hypothesizes that:

H5: board size has a significant positive impact on the level of voluntary disclosure.

\subsection{Board meetings frequency}

Lipton \& Lorsch (1992) argued that the main challenge being faced by the board of directors is the shortage of time to meet their responsibilities .frequency of board meetings is expected to simplify the flow of information and opinions and enhances the board effectiveness. Appuhami \& Tashako (2017), Allegrini \& Greco (2013), Laksmana (2008), Karamanou \& Vafeas (2005) provided evidences that board meetings frequency have a positive and significant impact on corporate disclosure. As such, the next hypothesis will be as follows;

H6: board meeting frequency has a significant positive impact on the level of voluntary disclosure.

\subsection{Board independence}

Agency theory argued that independent board members are more likely to have a critical role in enhancing the effectiveness of the board in performing monitoring functions (Fama \& Jensen, 1983). Consistent with the agency theory view, this paper argue that independent board members are more able to accomplish the monitoring functions over management practices related to the release of voluntary information, besides, The existence of independent board members is expected to increase the transparency of the company and reduce the information asymmetry among the company's owners and managers; Liu \& Chen (2016) have employed a sample of 516 listed firms in Taiwan to investigate the association between corporate governance attributes and disclosure quality; the results found that high levels of board independence and board activity have a significant positive effect on disclosure quality. Furthermore, the results provided evidence that family ownership positively moderated the relationship between board independence and disclosure quality, such behavior arise in order to enhance transparency and to gain legitimacy. Akhtaruddin et al. (2009) found a positive association between board independence and voluntary disclosure and between Board size and voluntary disclosure. However, the level of voluntary disclosure is negatively affected by family control, while, audit committee size has no impact on the level of voluntary disclosure. On the contrary, Nandi \& Ghosh (2012) provided evidence that family control enhances voluntary disclosure. In the same context, Altawalbeh (2020) found that independent board members do not guarantee to improve the performance of a firm, and it stays the firm's responsibility to choose independent board members who are able to exercise effective oversight function. The former discussion has led to the following hypotheses:

H7: Independent board members have a significant positive impact on the level of voluntary disclosure.

\subsection{Foreign ownership}

A key dimension of corporate governance is foreign ownership, the high proportion of foreign ownership would motivate potential investors and sends signal of the high level of trust, as such, and firm's 
management would seek to enhance the degree of attractiveness through voluntarily disclosing more information, suggesting that high level of corporate voluntary disclosure implies a high level of trust. Empirically, previous studies have detected a positive and significant relationship between the percentage of foreign ownership and the level of voluntary disclosure (Mangena \& Tauringana, 2007; Haniffa \& Cooke, 2002, Lam \& Shi, 2008), depending on the previous discussion, the next hypothesis would be as follows:

H8: foreign ownership has a significant positive impact on the level of voluntary disclosure.

\subsection{Institutional ownership}

Institutional ownership represents those shares owned by other institutions, which might be banks or other companies. Depending on the agency theory, a high institutional ownership ratio will have a greater role in urging management to provide high level of voluntary disclosure (Akhtaruddin et al., 2009). Shleifer \& Vishny (1997) argued that Institutional ownership have an important role in the supervision and control of management practices and in mitigating the conflict between management and shareholders. Thus, the next hypothesis will be as follows;

H9: institutional ownership has a significant positive impact on the level of voluntary disclosure.

\subsection{Family control}

Family controlled companies are expected to have higher power and motivations in monitoring management's actions. Alqatamin (2018) argued that family controlled companies are more likely to achieve high performance than non family companies suggesting that family controlled companies are more likely to be engaged in management and have better information about their investment. Giovannini (2010) suggests that family owned companies are more likely to release less transparent disclosures in the financial reports. Ho \& Wong (2001) find a negative relation between family controlled firms and the level of voluntary disclosure, following Prior researches (Chen \& Jaggi, 2000; Akhtaruddin et al., 2009; Alqatamin, 2018) this paper labels firms as family controlled if $10 \%$ or more of the common shares are owned by a the next hypothesis will be as follows:

H10: family control has a significant negative impact on the level of voluntary disclosure.

\section{Methodology of research}

\subsection{Data and Sample}

The initial sample of this study consisted of all public shareholding companies listed on (ASE) totaling 243 companies on 2013, this paper excluded companies classified under financial sector $(n=113)$ because the financial sector in Jordan has specific regulations of disclosure and governance released by the central bank of Jordan (JCB). The paper also excluded companies with unavailable date during the study period 2013-2016, the final sample consisted of 72 companies listed on (ASE). To obtain data necessary for this study, the publicly available annual financial reports were downloaded from (ASE) website.

\subsection{Variables measurements and Regression model}

This paper has employed the corporate voluntary disclosure as the dependent variable. Previous studies have created a voluntary disclosure index using a checklist that represents financial and nonfinancial items (Akhtaruddin \& Haron 2010; Allegrini \& Greco, 2013; Akhtaruddin et al., 2009; Cheng \& Courtenay, 2006, Barako et al., 2006; Mangena \& Pike, 2005; Madi et al., 2014) following previous studies, the current study employs a modified voluntary disclosure checklist of that used by Akhtaruddin \& Haron (2010) through reviewing the Jordanian legislation related to the disclosure instructions such as the Jordanian Companies Law and corporate governance regulations to exclude obligatory items, the final version of the modified voluntary disclosure checklist includes 18 items represents financial and nonfinancial information related to corporate governance and risks disclosure, corporate strategy and social responsibility (appendix $A$ ), each item will be given 1 if included in the disclosure checklist and 0 otherwise, finally, the total score is divided by the maximum disclosure score for a firm (18 item) to get the relative disclosure index ratio. 
Independent variables include audit committee characteristics and board attributes, following the stream of previous researches, audit committee size, audit committee meetings frequency, audit committee experience and audit committee independence were used to stand for audit committee characteristics, board attributes include board size, board independence, and board meetings frequency . This study also includes institutional ownership and family ownership. The current study also has control for the return on assets (ROA), leverage and the firm size. Table 1 below summarizes the study variables, labels and measurement.

This study has run the multiple regressions to investigate the impact of the explanatory variables on the corporate voluntary disclosure, as such; the following equation was estimated using (OLS):

$$
\begin{aligned}
& \text { CVD }=\beta 0+\beta 1 A C S I Z+\beta 2 A C M E E T+\beta 3 A C E X P+\beta 4 A C I N D+\beta 5 B S I Z+\beta 6 B I N D+\beta 7 B M E E T+\beta 8 I O W N+ \\
& \beta 9 F C+\beta 10 F O W N+\beta 11 R O A+\beta 12 L E V+\beta 13 F S I Z+\varepsilon
\end{aligned}
$$

\begin{tabular}{|c|c|c|c|}
\hline Variable & label & Description and measurement & Predicted sign \\
\hline \multicolumn{4}{|l|}{ Dependent variable } \\
\hline Corporate voluntary disclosure & CVD & Relative disclosure index ratio & \\
\hline \multicolumn{4}{|l|}{ Independent variables } \\
\hline Audit committee size & ACSIZ & Total number of Audit committee members & $(+)$ \\
\hline Audit committee meetings frequency & ACMEET & The number of audit committee meetings for the year & $(+)$ \\
\hline $\begin{array}{l}\text { Audit committee financial and } \\
\text { accounting experience } \\
\text { (audit committee expertise) }\end{array}$ & ACEXP & $\begin{array}{l}\text { The proportion of financial expertise on the audit } \\
\text { committee to the total audit members }\end{array}$ & $(+)$ \\
\hline Audit committee independence & ACIND & $\begin{array}{l}\text { The proportion of independent directors on the audit } \\
\text { committee to the total audit committee members }\end{array}$ & $(+)$ \\
\hline Board size & BSIZ & The total number of members on each board & $(+)$ \\
\hline Board independence & BIND & $\begin{array}{l}\text { Percentage of non executive } \\
\text { members to total board members }\end{array}$ & $(+)$ \\
\hline Board meetings & BMEET & The total number of board meetings during the year & $(+)$ \\
\hline Institutional ownership & IOWN & Percentage of shares owned by institutions & $(+)$ \\
\hline Family control & $\mathrm{FC}$ & $\begin{array}{l}\text { A dummy variable that takes } 1 \text { if classified as family } \\
\text { controlled and } 0 \text { otherwise }\end{array}$ & $(-)$ \\
\hline Foreign ownership & FOWN & Percentage of shares owned by foreigners & $(+)$ \\
\hline \multicolumn{4}{|l|}{ Control variables } \\
\hline Return on assets & ROA & Net income divided by total assets & ? \\
\hline leverage & LEV & Total debt divided by total equity & ? \\
\hline firm size & FSIZ & The total assets & $(+)$ \\
\hline
\end{tabular}

Table 1. Variables definition and measurement

\section{Results and discussions}

\subsection{Descriptive statistics}

Table 2 below presents the descriptive statistics for the study variables, the results indicate that the maximum corporate voluntary disclosure index rate is 85 percent, which means that some firms has succeed to disclose 85 percent of the checklist items. The minimum disclosure index rate is 5 percent, while on average the firm's voluntary disclosure index rate is 55 percent. These results indicate that the firms are widely distributed with respect to voluntary disclosure. The results also indicate that on average 76 percent of audit committee members are independent, meanwhile the minimum audit committee size of three members shows that firms cope with the requirements of Jordanian corporate governance guideline which require a minimum of three audit committee members. Audit committee meetings range from 1 to 10 meetings, in addition the results of audit committee experience show an average of 62 percent, this is consistent with the results of Alqatamin (2018) who found that more members with experience in accounting and finance have been appointed to the audit committees in the Jordanian firms. In terms of board attributes the results show that the average board size of 8.6, average board meetings of 5.6 are clear indications of the Jordanian firms adherence to Jordanian corporate governance guide line. In terms of ownership figures, foreign ownership range from 0 to 98.5 percent while the minimum and maximum institutional ownership range from 0 to 4.5 percent respectively, these results are consistent with Altawalbeh (2020). In terms of family control the results indicate that 16 percent are family owned companies with a minimum and maximum value of 0 and 99 percent respectively. In addition, the results 
show that on average leverage ratio is 44 percent which means that firms are highly dependent on long term debt as a portion of capital structure. Profitability range from -80 percent to 90 percent with a mean value of 26 percent which indicates that on average firms were financially successful.

Table 2. Descriptive statistics

\begin{tabular}{ccccc}
\hline Variable & MIN & MAX & MEAN & ST.DEV \\
\hline CVD & .05 & .85 & .55 & .17 \\
ACIND & .00 & 1.00 & .76 & .43 \\
ACMEET & 1.00 & 10.00 & 4.4 & 1.6 \\
ACSIZ & 3.00 & 8.00 & 3.9 & 1.1 \\
ACEXP & .24 & .78 & .62 & .58 \\
BSIZ & 3.00 & 14.00 & 8.6 & 2.6 \\
BMEET & 2.00 & 22 & 5.6 & 1.8 \\
BIND & .08 & 1.6 & .53 & .26 \\
FOWN & 0.0 & 98.5 & 5.5 & 14.8 \\
IOWN & 0.0 & 4.5 & .41 & .58 \\
FC & 0.0 & .99 & .16 & .21 \\
ROA & -.80 & .90 & .26 & .52 \\
FSIZ & .88 & 3.3 & 5.6 & 1.7 \\
LEV & 0.0 & 3.6 & .44 & .38 \\
\hline
\end{tabular}

\subsection{Multicollinearity}

Table 3 below presents data related to the correlation matrix used to check for the incidence of multicollinearity problem between the independent variables. Gujarati (2008) argued that 80 percent should be considered as the starting level of multicollineariry problem, the highest correlation value presented in table 2 is $71.2 \%$ between audit committee size (ACSIZ) and audit committee meetings frequency (ACMEET), as such this paper conclude that data used in this study is free from multicollinearity problem.

Table 3. Correlation matrix

\begin{tabular}{|c|c|c|c|c|c|c|c|c|c|c|c|c|c|}
\hline & ACIND & ACMEET & ACSIZ & ACEXP & BSIZ & BMEET & BIND & FOWN & IOWN & FC & ROA & FSIZ & LEV \\
\hline ACIND & 1 & & & & & & & & & & & & \\
\hline ACMEET & $.645^{* *}$ & 1 & & & & & & & & & & & \\
\hline ACSIZ & $.414^{*}$ & $.712 * *$ & 1 & & & & & & & & & & \\
\hline ACEXP & $.458^{*}$ & .065 & .073 & 1 & & & & & & & & & \\
\hline BSIZ & .054 & .101 & .142 & .054 & 1 & & & & & & & & \\
\hline BMEET & .091 & .134 & .092 & .255 & -.092 & 1 & & & & & & & \\
\hline BIND & .053 & .053 & .366 & .056 & -.227 & $.453^{*}$ & 1 & & & & & & \\
\hline FOWN & .009 & .036 & -.061 & .008 & -.026 & .005 & .364 & 1 & & & & & \\
\hline IOWN & .018 & -.020 & -.039 & .059 & -.215 & .017 & -.021 & .094 & 1 & & & & \\
\hline FC & -.080 & .133 & .248 & .006 & $.668 * *$ & .033 & $-.699 * *$ & .005 & .081 & 1 & & & \\
\hline ROA & -.041 & .023 & .012 & .044 & .007 & -.035 & .035 & .084 & -.038 & -.041 & 1 & & \\
\hline FSIZ & .057 & .084 & .009 & .007 & -..075 & -.047 & -.109 & .052 & .012 & .006 & .031 & 1 & \\
\hline LEV & .044 & -.009 & -.063 & .017 & -.073 & .044 & -.043 & -.063 & .023 & & -.180 & -.033 & 1 \\
\hline
\end{tabular}

\subsection{Regression analysis results}

Table 4 below presents the results of the multiple regression analysis in this paper, the results indicate an R-square of .828 and an adjusted R-square of .819 , in addition, the $F$ value is 93.301 which is highly significant at 0.000 level; these results indicate that a significant percentage of the variation in the corporate voluntary disclosure can be explained by the variations in the independent variables as a whole. With respect to audit committee characteristics, the results revealed that audit committee independence has a positive and significant impact on the level of corporate voluntary disclosure with a coefficient of .236 and significant at .000 , thus, hypothesis 1 is supported, suggesting that audit committee independence has a positive and significant impact on corporate voluntary disclosure. This result suggests that independent audit committee members would enhance the transparency of the firm's financial reports and improve the level of voluntary disclosure by effectively monitor the reporting process. This result is consistent with (Madi et al., 2014; Duchin et al., 2010; Taylor et al., 2011; Akhtaruddin \& Haron 2010). 
The results also indicate that audit committee meetings frequency has a positive and significant impact on the level of corporate voluntary disclosure with a coefficient of .732 and significant at .000 , thus, hypothesis 2 is supported. This result suggests that more audit committee meetings in a regular basis would enhance the effectiveness of the monitoring function ability to perform its monitoring function. This result is consistent with previous studies (Appuhami \& Tashako, 2017; Kelton \& Yang, 2008). Audit committee size shows a positive but insignificant impact on the level of corporate voluntary disclosure, this result is consistent with Mangena \& Pike (2005) who found no association between the size of audit committee and the level of voluntary disclosure, hence, the third hypothesis concerning the impact of audit committee size was not supported. Hypothesis 4 was rejected as our results provide insignificant impact of audit committee expertise on the level of corporate voluntary disclosure, Madi et al. (2014) has explained that by the need for domain knowledge of accounting, and finance to efficiently assess the reported information. This result is consistent with Appuhami \& Tashakor (2017), Madi et al. (2014); Othman et al., (2014) who found no significant association between financial expertise of audit committee members and voluntary disclosure.

Our results provide insignificant negative impact of board size on the level of voluntary disclosure, thus, hypothesis 5 is rejected, this result is consistent with (Lipton \& Lorsh, 1992) who argued that large board size is expected to be less effective in performing monitoring functions as a result of poor consensus which is expected to result in low level of corporate disclosure. The coefficient of board independence is .142 and significant at .044 level, this result support hypothesis 7 suggesting that board independence would have a significant positive impact on the level of corporate voluntary disclosure, this result is consistent with the agency theory which argued that independent board members are more likely to effectively perform monitoring functions (Fama \& Jensen, 1983). In addition, the existence of independent board members is expected to enhance the transparency of the financial reporting process. This result is consistent with previous studies (Liu \& Chen, 2016; Akhtaruddin et al., 2009). The coefficient of Foreign ownership was .064 and exerts a significant impact at .040 level, the findings support hypothesis 8 suggesting that foreign ownership would positively impact the level of corporate voluntary disclosure, this is consistent with the view that companies would enhance the level of voluntary disclosure to demonstrate high level of trust which implies a reduction in information asymmetry (Mangena \& Turingana, 2007), this result is consistent with previous studies (Haniffa \& Cooke, 2002, Lam \& Shi, 2008). Family control coefficient is -.073 and significant at .028 level suggesting that the higher the proportion of family ownership, the lower the level of voluntary disclosure, this result supports hypothesis 10, this result is consistent with the view that family owned firms are more likely to disclose less transparent information in the financial reports (Giovannini , 2010).

Table 4. Regression results

\begin{tabular}{ccccc}
\hline & Coefficients & Std.Error & t.values & Significance \\
\hline constant & & 2.968 & 5.160 & .000 \\
ACIND & .236 & 1.473 & 5.910 & $.000^{*}$ \\
ACMEET & .732 & .675 & 11.285 & $.000^{*}$ \\
ACSIZ & .018 & .759 & .324 & .746 \\
ACEXP & .0531 & .456 & 1.125 & .245 \\
BSIZ & -.037 & .191 & -1.172 & .243 \\
BMEET & .018 & .253 & .604 & .546 \\
BIND & .142 & .325 & .943 & $.044^{* *}$ \\
FOWN & .064 & .032 & 2.068 & $.040^{* *}$ \\
IOWN & -.016 & 1.436 & -.493 & .622 \\
FC & -.073 & 2.105 & -1.198 & $.028^{* *}$ \\
ROA & .041 & 1.860 & 1.320 & .188 \\
FSIZ & -.041 & .017 & -1.359 & .326 \\
LEV & .031 & 2.011 & .984 & \\
R-square & .828 & & & \\
Adjusted R-square & .819 & & & \\
F value & 93.301 & & & \\
F significance & .000 & & & \\
Dependent variable & CVD & & & \\
\hline
\end{tabular}




\begin{tabular}{cccc}
\hline Coefficients & Std.Error & t.values & Significance \\
\hline${ }^{*}$ Significant at $1 \%,{ }^{* *}$ Significant at $5 \%$. & & \\
\hline
\end{tabular}

Table 5. Summary of hypotheses and outcomes

\begin{tabular}{|c|c|c|}
\hline & Description & Outcome \\
\hline $\mathrm{H} 1$ & Audit committee independence has a significant positive impact on the level of voluntary disclosure & Supported \\
\hline $\mathrm{H} 2$ & $\begin{array}{l}\text { Audit committee meeting frequency has a significant positive impact on the level of voluntary } \\
\text { disclosure }\end{array}$ & Supported \\
\hline H3 & Audit committee size has a significant positive impact on the level of voluntary disclosure & Not supported \\
\hline $\mathrm{H} 4$ & Audit committee expertise has a significant positive impact on the level of voluntary disclosure & Not supported \\
\hline H5 & Board size has a significant positive impact on the level of voluntary disclosure. & Not supported \\
\hline H6 & Board meeting frequency has a significant positive impact on the level of voluntary disclosure. & Not supported \\
\hline $\mathrm{H} 7$ & Independent board members have a significant positive impact on the level of voluntary disclosure. & Supported \\
\hline $\mathrm{H} 8$ & Foreign ownership has a significant positive impact on the level of voluntary disclosure. & Supported \\
\hline H9 & Institutional ownership has a significant positive impact on the level of voluntary disclosure. & Not supported \\
\hline $\mathrm{H} 10$ & Family control has a significant negative impact on the level of voluntary disclosure. & Supported \\
\hline
\end{tabular}

\section{Conclusions}

The purpose of this study was to investigate the impact of audit committee characteristics, board attributes on the level of corporate voluntary disclosure. Audit committee characteristics include; audit committee independence, audit committee meetings frequency, audit committee size, and audit committee accounting and financial experience. Board attributes include; board size, board meetings frequency and board independence, In addition, the impact of foreign ownership percentage, institutional ownership and family control on the level of corporate voluntary disclosure were also investigated. Finally, this study controlled for profitability, firm's size and leverage as suggested by previous studies. The level of voluntary disclosure was measured using the index rate for a sample of 72 non-financial firms. The findings of this study have several implications; the results revealed that independent audit committee members and more frequent meetings of the audit committee are associated with high level of voluntary disclosure and related to higher level of transparency. The findings also suggest that board independence plays a vital role in enhancing corporate transparency in the form of a higher level of voluntary disclosure. Important findings propose that family controlled companies are associated with lower level of voluntary disclosure, supporting the view that family controlled firms are less likely to provide transparent information. This study is limited to no-financial listed firms, hence, the findings may not generalized to all sectors, another limitation is the sensitivity of using an index rate to measure the level of voluntary disclosure as the selection of the items included in the checklist may affect the results. Future research may include all sectors including the financial sectors; future research may also include additional characteristics of audit committee such as audit committee tenure.

\section{References}

1. Ahmed, K., Hossain, M., \& Adams, M. B. (2006). The effects of board composition and board size on the in formativeness of annual accounting earnings. Corporate Governance, 14(5), 418-431.

2. Akhtaruddin, M., \& Haron, H. (2010). Board ownership, audit committees' effectiveness, and corporate voluntary disclosures. Asian Review of Accounting, 18(3), 245-259.

3. Akhtaruddin, M., Hossain, M. A., Hossain, M., \& Yao, L. (2009). Corporate governance and voluntary disclosure in corporate annual reports of Malaysian listed firms. Journal of Applied Management Accounting Research, 7(1), 1.

4. Allegrini, M., \& Greco, G. (2013). Corporate boards, audit committees and voluntary disclosure: evidence from Italian listed companies. Journal of Management and Governance, 17 (1), 187-216.

5. Alqatamin, R. M. (2018). Audit committee effectiveness and company performance: Evidence from Jordan. Accounting and Finance Research, 7(2), 48.

6. Altawalbeh, M. A. (2020). Corporate Governance Mechanisms and Firm's Performance: Evidence from Jordan. Accounting and Finance Research, 9, 11. 
7. Appuhami, R., \& Tashakor, S. (2017). The impact of audit committee characteristics on CSR disclosure: An analysis of Australian firms. Australian Accounting Review, 27(4), 400.

8. Barako, D. G., Hancock, P., \& Izan, H. Y. (2006). The relationship between corporate governanceattributes and voluntary disclosure in annual reports: The Kenyan experience. FinancialReporting, Regulation, and Governance, 5(1), 1-25.

9. Bedard, J., Coulombe, D., \& Courteau, L. (2008). Audit committee, underpricing of IPOs, andaccuracy of management earnings forecasts. Corporate Governance: An International

10. Ben Kwame Agyei-Mensah. (2018) "The effect of audit committee effectiveness and audit quality on corporate voluntary disclosure quality", African Journal of Economic and Management Studies, https://doi.org/10.1108/AJEMS-04-2018-0102

11. Cheng, E., \& Courtenay, S. (2006). Board composition, regulatory regime and voluntary disclosure. The International Journal of Accounting, 41(3), 262-289. http://dx.doi.org/10.1016/ j.intacc.2006.07.001.

12. DeZoort, F. T., Hermanson, D. R., Archambeault, D. S., and Reed, S. A. (2002), "Audit Committee Effectiveness: A Synthesis of the Empirical Audit Committee Literature", Journal of Accounting Literature, Vol. 21. pp. 38-75.

13. Duchin, R., Matsusaka, J. G., \& Ozbas, O. (2010). When are outside directors effective?. Journal of financial economics, 96(2), 195-214.

14. Erer, M., \& Dalgic, O. M. (2011). The impact of corporate governance on internet financial reporting: Evidence from Turkey. International Journal of Business Research, 11(3), 2646.

15. Fama, E. F., \& Jensen, M. C. (1983). Agency problems and residual claims. The journal of law and Economics, 26(2), 327-349.

16. Gandía, J. L. (2008). Determinants of internet-based corporate governance disclosure by Spanish listed companies. Online Information Review, 32 (6), 791-817.

17. Gregory, H. J. (2009). Comparison of corporate governance guidelines and codes of best practices. Available at: http://www.weil.com/files/Publication/1c418175-0e4c-47ac-9341-97df376b5ae2/ Presentation/.

18. Habbash, M. (2010), "The effectiveness of corporate governance and external audit on constraining earnings management practice in the UK", doctoral thesis, Durham University, available at: http://etheses.dur.ac.uk/448/.

19. Haniffa, R., \& Cooke, T. (2002). Culture, corporate governance and disclosure in Malaysian corporations. ABACUS: Journal of Accounting, Finance and Business Studies, 38(3), 317-349. http://dx.doi.org/10.1111/1467-6281.00112.

20. HERATH, S., \& Altamimi, S. (2017). Corporate governance and voluntary disclosure: A Literature Review. American International Journal of Humanities and Social Science, 3(4), 34-45.

21. Ho, S. S. M., \& Wong, K. S. (2001). A study of the relationship between corporate governance structures and the extent of voluntary disclosure. Journal of International Accounting,Auditing \& Taxation, 10, 139-156.

22. Ho, S. S., \& Wong, K. S. (2001). A study of the relationship between corporate governance structures and the extent of voluntary disclosure. Journal of International Accounting, Auditing and Taxation, 10(2), 139-156.

23. Huang, H., \& Thiruvadi, S. (2009). Audit committee characteristics and corporate fraud.International Journal of Public Information Systems, 71-82.

24. Laksmana, I. (2008). Corporate Board Governance and Voluntary Disclosure of Executive Compensation Practices. Contemporary Accounting Research, 25(4), 1147-1182.

25. Larmou, S., \& Vafeas, N. (2010). The relation between board size and firm performance in firms with a history of poor operating performance. Journal of Management and Governance, 14, 61-85.

26. Li, J., Mangena, M., \& Pike, R. (2012). The effect of audit committee characteristics on intellectual capital disclosure. The British Accounting Review, 44(2), 98-110.

27. Lipton, M., \& Lorsch, J. W. (1992). A modest proposal for improved corporate governance. The business lawyer, 59-77.

28. Liu, Y., Valenti, A., \& Chen, Y. (2016). Corporate governance and information transparency in Taiwan's public firms: The moderating effect of family ownership. Journal of Management \& Organization, 22(5), 662-679. doi:10.1017/jmo.2015.56. 
29. Madi, H., Ishak, Z., \& Manaf, N. A. A. (2014). The impact of audit committee characteristics on corporate voluntary disclosure. The impact of audit committee characteristics on corporate voluntary disclosure, 164.

30. Mangena, M., \& Pike, R. (2005). The effect of audit committee shareholding, financial expertise and size on interim financial disclosures. Accounting and Business Research, 35(4), 327- 349.

31. Mangena, M., \& Tauringana, V. (2007). Disclosure, corporate governance and foreign share ownership on the Zimbabwe stock exchange. Journal of International Financial Management and Accounting, 18(2), 53-85.http://dx.doi.org/10.1111/j.1467-646X.2007.01008.x

32. Martinez, M., \& Fuentes, C. (2007). The Impact of Audit Committee Characteristics on the Enhancement of the Quality of Financial Reporting: an empirical study in the Spanish context. Corporate Governance, 15(6): $1394-1412$.

33. Moxey, P. (2004). Corporate Governance and Wealth Creation, Occasional Research Paper No. 37, The Association of Chartered Certified Accountants, London.

34. Nandi, S., \& Ghosh, S. K. (2012). Corporate governance attributes, firm characteristics and the level of corporate disclosure: Evidence from the Indian listed firms. Decision Science Letters, 2, 45-58.

35. Othman, R., Ishak, I. F., Arif, S. M. M., \& Aris, N. A. (2014). Influence of audit committee characteristics on voluntary ethics disclosure. Procedia-Social and Behavioral Sciences, 145, 330-342.

36. Persons, O. S. (2009). Audit committee characteristics and earlier voluntary ethics disclosure among fraud and no-fraud firms. International Journal of Disclosure and Governance, 6(4), 284-297.

37. Rahman, R. A. (2011). Institutional investors and board of directors' monitoring

38. Taylor, D., \& Zhang, J. X. (2011). Corporate risk disclosures: the influence of institutional shareholders and the audit committee. Journal of Corporate Finance, 9(1), 1-27.

\title{
Appendix A: voluntary disclosure items
}

\author{
Strategic Information \\ The company's history \\ organizational structure \\ corporate strategy and objectives. \\ Predictions on: \\ Revenues \\ earnings \\ Systematic risks \\ Un systematic risks \\ cash flows \\ Non-financial Information \\ Board structure information \\ Directors CV's (qualifications, expertise...etc). \\ Directors remunerations \\ Board ownership \\ Social aspect \\ employees list and positions \\ Donations. \\ Social activities Sponsoring \\ Financial Information \\ Comparative financial statements for at least 2 years at least \\ Growth rate \\ Market capitalization \\ Impact of foreign exchange fluctuations on Current results.
}

